\title{
Melolabial fold interpolated flap for reconstruction of complex nasal defects"
}

\section{Retalho interpolado do sulco melolabial para reconstrução de defeitos complexos do nariz}

\author{
Pedro Andrade ${ }^{1}$ \\ José Carlos Cardoso \\ Américo Figueiredo ${ }^{3}$
}

\author{
David Serra ${ }^{1}$ \\ Ricardo Vieira ${ }^{2}$
}

\begin{abstract}
Complex surgical nasal defects are often technically difficult. We report the case of a 71-year old male diagnosed with a malignant melanoma (animal type; Breslow 1.5; Clark IV) on the right nasal ala. Radial excision with margins of approximately $1.5 \mathrm{~cm}$ was performed, creating a complex full-thickness surgical defect involving the free wall and margin of the right nasal ala, the right soft triangle, nasal lobe and columella, which was reconstructed using a melolabial interpolated flap, with highly satisfactory final esthetic result. Interpolated flaps are viable surgical options for the reconstruction of surgical defects for which local flaps and skin grafts are not suitable.
\end{abstract}

Keywords: Melanoma; Nose; Surgical flaps

Resumo: A reconstrução de defeitos cirúrgicos complexos do nariz é, por norma, tecnicamente difícil. Apresentamos um doente do sexo masculino, de 71 anos, referenciado após biopsia excisional de melanoma maligno de tipo animal (Breslow $1,5 \mathrm{~mm}$, Clark IV) da asa direito do nariz. O alargamento excisional com margem de $1,5 \mathrm{~cm}$ originou um defeito complexo envolvendo a asa nasal direita, o triângulo mole direito, o lobo nasal e a columela, que foi reconstruído por retalho interpolado do sulco melolabial, com resultado cosmético final bastante satisfatório. Os retalhos interpolados são opções cirúrgicas eficazes para reconstrução de defeitos cutâneos para os quais a realização de retalhos locais não é possível e a colocação de enxertos inviabiliza um resultado cosmético aceitável.

Palavras-chave: Melanoma; Nariz; Retalhos cirúrgicos

\section{INTRODUCTION}

Reconstruction of surgical nasal defects is a regular challenge in daily dermatological practice, imposed by the complexity of local anatomy and its particular cosmetic relevance. The existence of distinct cosmetic units, with variable skin textures and thickness, the anatomic complexity of the nasal structures, and particularly the low mobility of local skin are the main factors that make the reconstruction of large nasal defects technically difficult. Many diffe- rent techniques have been described for nasal defects where primary closure is not an option, each one of them based on different perinasal donor skin areas and offering distinct specificities, advantages and risks.

\section{CLINICAL CASE}

We present the case of a white 71-year-old male patient, who was referred to our Dermatology

Received on 10.06.2011.

Approved by the Advisory Board and accepted for publication on 22.08.2011.

* Study carried out at the Teaching Hospitals of University of Coimbra (Universidade de Coimbra, EPE Serviço de Dermatologia e Venereologia) - Coimbra, Portugal.

Conflict of interest: None

Financial funding: None

M.D - Intern of Dermatology and Venereology - Teaching Hospitals of University of Coimbra (Universidade de Coimbra, EPE Serviço de Dermatologia e Venereologia) - Coimbra, Portugal.

M.D - Specialist in Dermatology and Venereology - Hospital Assistant - Teaching Hospitals of University of Coimbra (Universidade de Coimbra, EPE Serviço de Dermatologia e Venereologia) - Coimbra, Portugal.

Ph.D - Professor-doctor - Specialist in Dermatology and Venereology - Director of the Dermatology and Venereology Service - Teaching Hospitals of University of Coimbra (Serviço de Dermatologia e Venereologia - Hospitais da Universidade de Coimbra, EPE Serviço de Dermatologia - Coimbra, Portugal. 
Department soon after tight-margin excision of a nonulcerated animal type malignant melanoma (Breslow 1.5, Clark IV) located on the anterior border of the right nasal ala. ${ }^{1,2}$ This patient had antecedents of prostatic adenocarcinoma, surgically treated by transurethral resection 4 years before, and chronic auricular fibrillation with normal ventricular response, justifying long-term antiaggregation with acetylsalicylic acid 100mg o.d.. No other significant medical conditions or familial antecedents were reported.

A linear $0.5 \mathrm{~cm}$ long parasagittal scar was observed on the anterior aspect of the right nasal ala, close to the ipsilateral nasal soft triangle (Figure 1). No evidence of persistent local pigmented lesion was noticed and no other suspicious melanocytic lesions were observed. Preauricular, cervical and supraclavicular lymph nodes were not enlarged, and a complete clinical examination was considered normal.

Cervical, thoracic and abdominopelvic tomodensitometric exams were performed and did not reveal any secondary lesions. As a consequence, the patient was admitted for radial re-excision of the nasal scar and right mandibular sentinel lymph node selective biopsy, under general anesthesia. Radial reexcision was performed with margins of less than $1.5 \mathrm{~cm}$ due to the specific limitations of the affected anatomic area, originating a complex $3 \mathrm{~cm}$-wide fullthickness surgical defect involving the free wall and margin of the right nasal ala, the right soft triangle, the nasal lobe and the columella (Figure 2). Surgical reconstruction of this defect was performed using a two-stage melolabial interpolated flap. In the first stage, donor skin with approximately the same size of the surgical nasal defect was collected from the right cheek, adjacent to the right melolabial fold (Figure 2). The resulting secondary defect was primarily closed after prolongation of the incision along the distal melolabial fold towards the ipsilateral oral commissu- re. Then, after removal of excessive subcutaneous cellular tissue, donor skin was transposed and directly sutured onto the nasal surgical defect (Figure 3). The second stage occurred 21 days later, under local anesthesia, and consisted in the section of the vascular pediculus.

Right submandibular sentinel lymph node was identified and selectively biopsied through a small local skin incision during the first surgical stage.

No incidents were reported following both surgeries, and the resulting scar was cosmetically satisfactory, as most of its extension was hidden on the melolabial and nasolabial anatomic folds and, therefore, imperceptible, maintaining the structure and function of the nasal pyramid (Figure 4).

The histological analysis of the sentinel lymph node revealed a single malignant melanoma subcapsular micrometastasis measuring less than $0.2 \mathrm{~mm}$, justifying right cervical radical lymphadenectomy. None of the 13 excised lymph nodes had histological evidence of malignant melanoma metastization. Additionally, no signs of melanocytic proliferation were detected in the excised nasal skin. Therefore, malignant melanoma was staged as IIIA (T2a,N1a,M0) according to the criteria defined by the American Joint Committee on Cancer and no evidence of active disease has been detected in the following 40 months.

\section{DISCUSSION}

Interpolation flaps, by definition, are supported by donor-skin areas that are not immediately adjacent to the surgical defect. They consist in pediculated cutaneous flaps, based on the rotation of a distant skin fragment around the axis of a vascular pediculus, responsible for their irrigation. ${ }^{3}$ These flaps are viable surgical options for reconstructing surgical defects in areas lacking sufficient surrounding movable skin for primary closure or local conventional flaps, or with
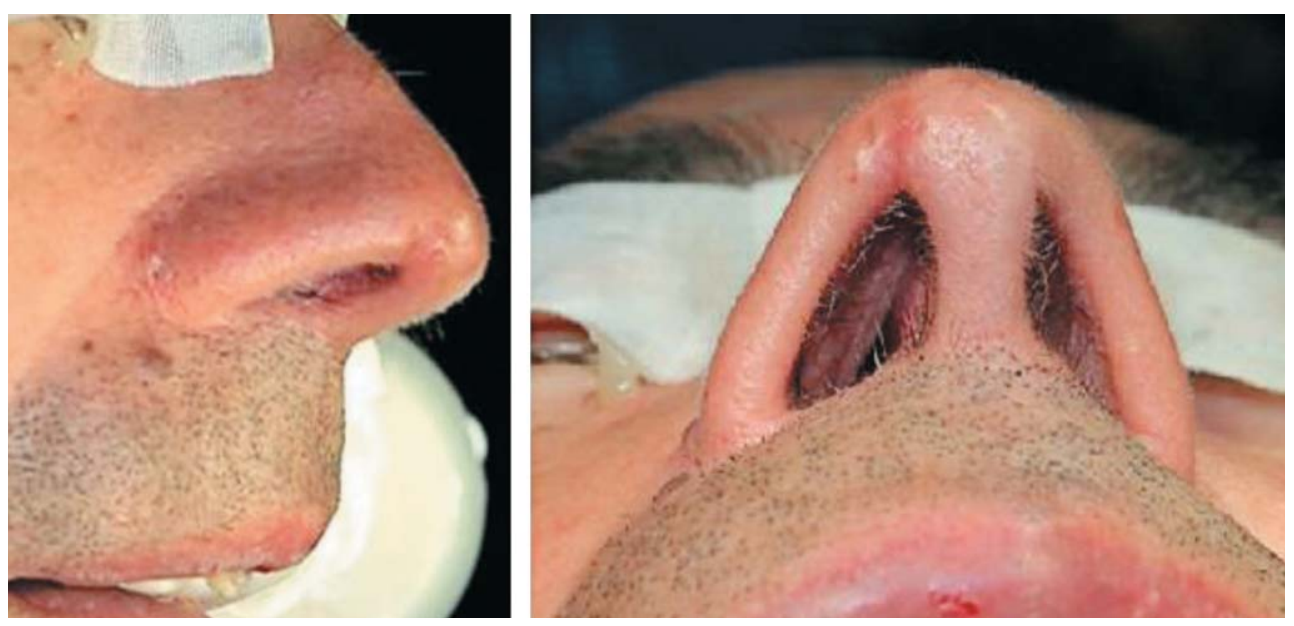

FiguRe 1: Linear parasagittal scar on the anterior border of the right nasal ala, resulting from the excisional biopsy of a non ulcerated animal type malignant melanoma (Breslow 1.5, Clark IV) 


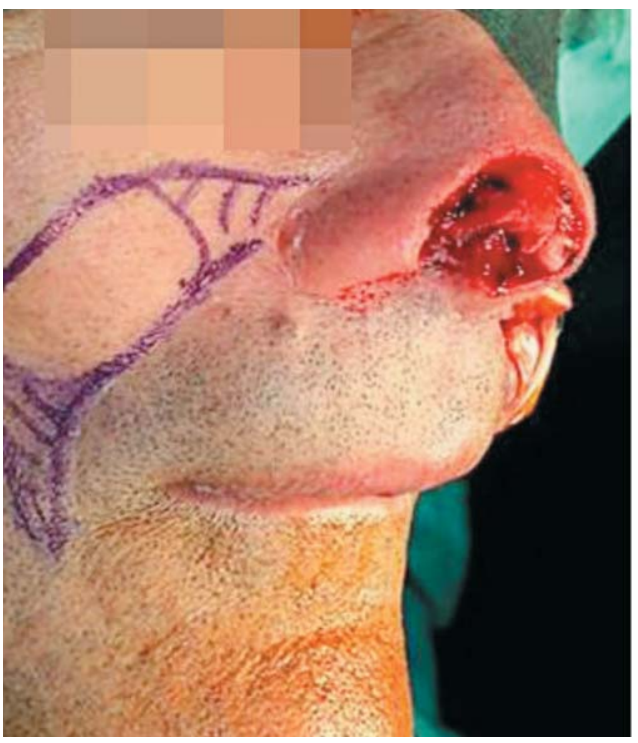

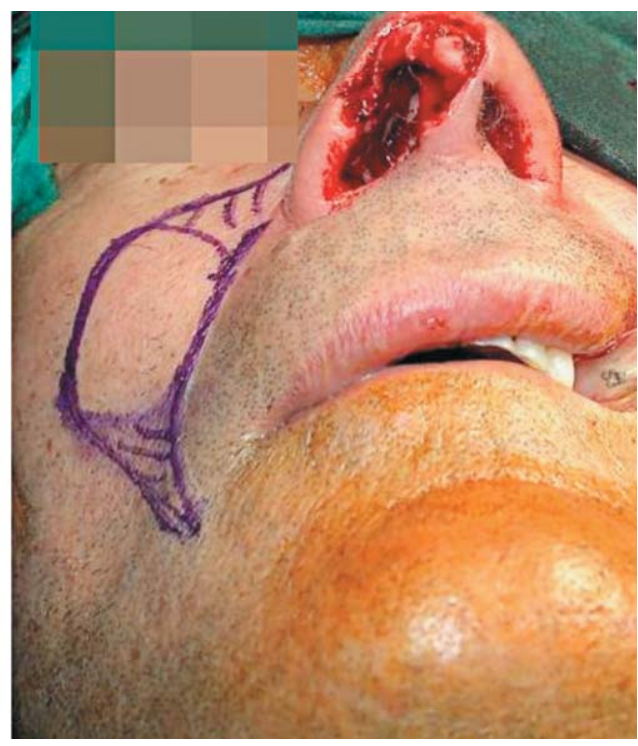

Figure 2: Complex surgical defect involving the border of the right nasal ala, the right soft triangle, the nasal lobe and the columella, after local radial re-excision with margins of $1.5 \mathrm{~cm}$ reduced vascular support, particularly on cartilage or bone surfaces.

Melolabial interpolated flaps rely on a wide area of highly irrigated cheek tissue that can easily be adapted to the complex tridimensional structure of the nasal pyramid and nasal alae. ${ }^{3,4,5}$ Their irrigation variably depends on different arterial vessels, such as angular artery, superior labial artery, infraorbitary artery and dorsal nasal artery. ${ }^{5}$ This particular arterial supply, in association with the large mobility of cheek soft tissues, turns melolabial interpolated flaps into highly versatile procedures. However, the inexistence of a well-defined vascular axis may also be a limiting factor, concerning the limits and extension of the donor area and its vascular viability. Still, due to the rich vas- cular supply, these flaps offer a very low risk of ischemic failure when used for closure of defects under $2.5 \mathrm{~cm}$ diameter. ${ }^{5}$

The technical procedure is very simple, and can be performed under local anesthesia - in the present case, general anesthesia was justified by the simultaneous cervical lymph node biopsy, for diagnostic and prognostic purposes. ${ }^{4,6}$ Despite consisting of twostage surgical procedures and requiring a three-week long interval between interventions, interpolated melolabial flaps respect the facial cosmetic units and originate scars that are partially hidden on perinasal anatomic folds, offering highly acceptable cosmetic results $^{4,5}$. In some cases, they may be used in association with local cartilage grafts in order to maintain the
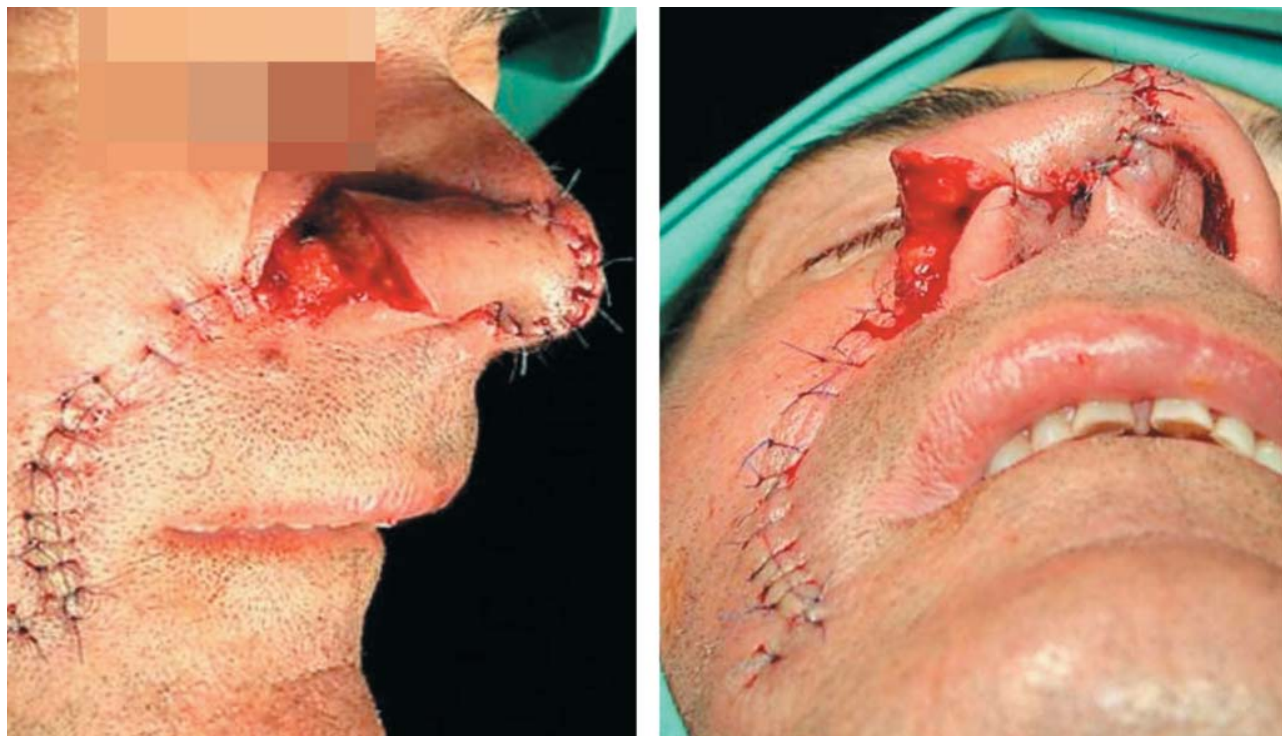

FIGURE 3: Detail of the surgical reconstructive procedure, after transposition of the interpolated melolabial flap to the nasal defect and primary closure of resulting secondary defects 


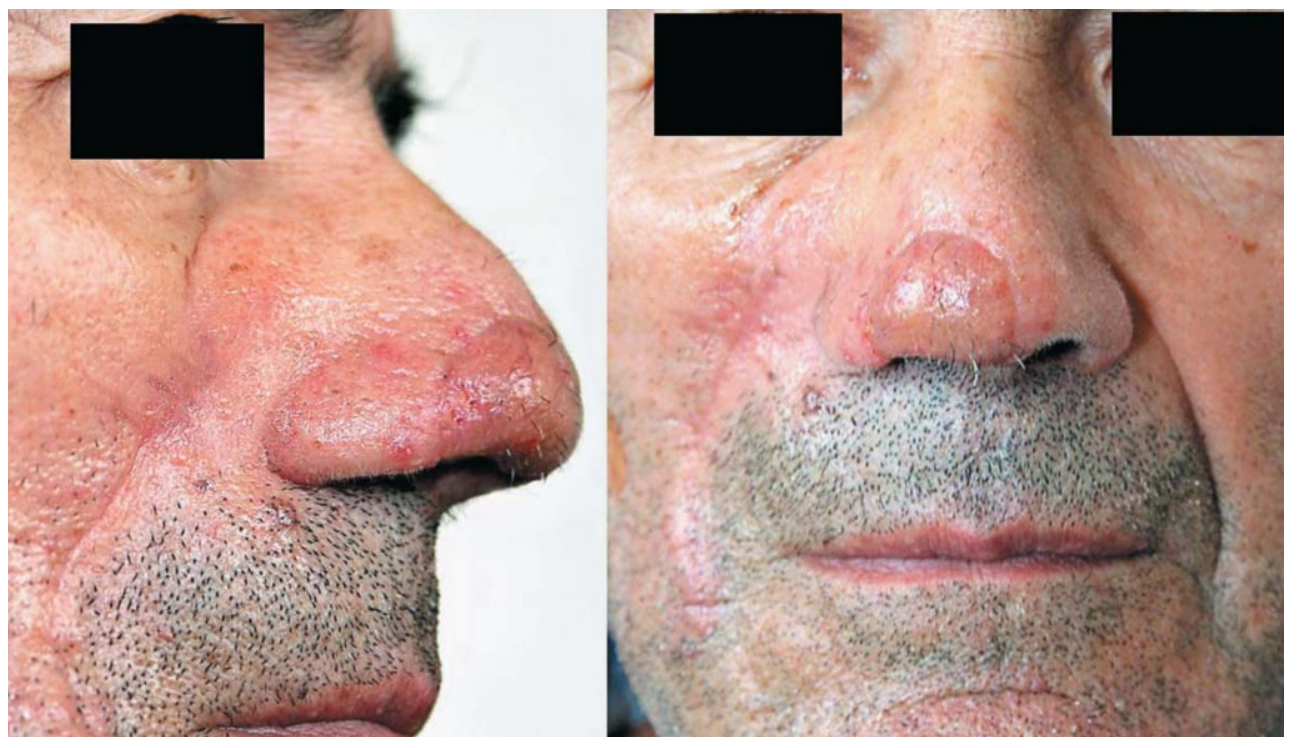

FIGURE 4: Interpolated melolabial flap - final result two months after surgery consistency and structure of the nasal pyramid and nasal alae, and consequently, the permeability of nasal airways. ${ }^{5}$

Other interpolated flaps have also been described for extensive surgical defects located in distinct facial areas: the paramedian forehead interpolation flap is supplied by the supratrochlear artery and is frequently used for reconstruction of nasal pyramid and alae defects; similarly, the retroauricular interpolation flap depends on multiple arterial branches and is a viable option for reconstruction of ear defects, particularly if located in the helix or antihelix ${ }^{3,7,8}$

\section{REFERENCES}

1. Ludgate MW, Fullen DR, Lee J, Rees R, Sabel MS, Wong SL, et al. Animal-type melanoma: a clinical and histopathological study of 22 cases from a single institution. Br J Dermatol. 2010;162:129-36.

2. Antony FC, Sanclemente G, Shaikh H, Trelles AS, Calonje E. Pigment synthetizing melanoma (so-called animal type melanoma): a clinicopathological study of 14 cases of a poorly known distinctive variant of melanoma. Histopathology. 2006;48:754-62.

3. Mellette JR, Ho DQ. Interpolation flaps. Dermatol Clin. 2005;23:87-112.

4. Barlow RJ, Swanson NA. The nasofacial interpolated flap in reconstruction of the nasal ala. J Am Acad Dermatol. 1997;36:965-9.

5. Lindsey WH. Reliability of the melolabial flap for alar reconstruction. Arch Facial Plast Surg. 2001;3: 33-7

6. Lages RB, Vieira SC, Abreu BA, Rodrigues IN, Santos LG, Cordeiro NM. Sentinel lymph node biopsy in cases of skin melanoma: initial experiences at a center in northeastern Brazil. An Bras Dermatol. 2011;86:379-82.
7. Jewett BS. Interpolated forehead and melolabial flaps. Facial Plast Surg Clin North Am. 2009;17:361-77.

8. Johnson TM, Fader DJ. The staged retroauricular to auricular direct pedicle (interpolation) flap for helical ear reconstruction. J Am Acad Dermatol. 1997;37:975-8.

\footnotetext{
MAILING ADDRESS / ENDEREÇO PARA CORRESPONDÊNCIA:

Pedro Andrade

Serviço de Dermatologia e Venereologia -

Hospitais da Universidade de Coimbra, EPE

Praceta Mota Pinto

3000-075 - Coimbra, Portugal

E-mail: pedro.andrade@portugalmail.com
}

How to cite this article: Andrade P, Serra D, Cardoso JC, Vieira R, Figueiredo A. Melolabial fold interpolated flap for reconstruction of complex nasal defects. An Bras Dermatol. 2012;87(5):762-5. 